\title{
WELVAART
}

\section{RESILIENSI PEMULUNG DI KELURAHAN PETOAHA KECAMATAN NAMBO KOTA KENDARI}

Muhammad Yasir, Muhammad Arsyad dan Dewi Anggraini

Fakultas Ilmu Sosial dan Ilmu Pilitik Universitas Halu Oleo

Email: muh.yasir@gmail.com

\begin{abstract}
ABSTRAK
Tujuan dari penelitian ini adalah untuk mengetahui kondisi kebutuhan dasar pemulung dan untuk mengetahui resiliensi pemulung dalam memenuhi kebutuhan dasarnya di Kelurahan Petoaha Kecamatan Nambo Kota Kendari. Metode penelitian yang digunakan dalam penelitian ini adalah kualitatif dengan menggunakan teknik pengumpulan data berupa observasi, wawancara, dan studi dokumentasi. Informan dalam penelitian ini sebanyak 14 orang yang terdiri dari 8 orang pemulung yang ada di Kelurahan Petoaha, 1 orang pembeli barang bekas, 3 orang Aparat Kelurahan Petoaha, dan 2 orang pegawai Dinas Sosial. Setelah seluruh informasi dikumpulkan, baik melalui proses observasi, wawancara maupun studi dokumentasi maka selanjutnya peneliti melakukan analisis data dengan cara deskriptif kualitatif. Hasil penelitian menunjukkan ada lima jenis kebutuhan pemulung yang dapat digolongkan dalam kebutuhan dasar yaitu kebutuhan sandang (pakaian), pangan (makanan), papan (perumahan atau tempat tinggal), kesehatan dan pendidikan. Sedangkan kemampuan individu pemulung dalam memenuhi kebutuhan dasarnya atau disebut juga resiliensi pemulung dalam memenuhi kebutuhan dasarnya dapat dilihat dari empat aspek. Pertama, social compentence yaitu kemampuan sosial pemulung yang ditunjukkan melalui saling berbagi makanan kepada tetangga dan saling bantu mengangkat hasil pulungan. Kedua, problem solving skill yaitu kemampuan memecahkan masalah yang ditunjukkan oleh pemulung melalui memperbanyak frekuensi memulung dan mencari kerang serta menjualkan hasil tangkapan nelayan. Ketiga, autonomy yaitu kemampuan pemulung yang ditunjukkan melalui kemampuannya untuk mengabaikan pandangan negatif yang datang dari orang lain dan tetap menilai positif pekerjaannya sebagai pemulung. Keempat, sense of purpose yaitu kemampuan pemulung yang ditunjukkan dengan kesadaran akan pentingnya pendidikan dan menaruh harapan besar pada anaknya agar mampu menyelesaikan sekolahnya paling rendah hingga jenjang Sekolah Menengah Atas.
\end{abstract}

Kata Kunci: Resiliensi, Pemulung, Kebutuhan Dasar

\section{PENDAHULUAN}

Setiap individu manusia menginginkan pekerjaan yang layak agar dapat dengan mudah menunjang kebutuhan hidupnya dan keluarganya. Akan tetapi, sebagian manusia tidak dapat mencapai keinginan ini disebabkan oleh beberapa hal. Seperti halnya bekerja sebagai pemulung. Orang memilih bekerja sebagai 


\section{WELVAART}

pemulung karena masalah pendidikan rendah dan kurangnya keterampilan. Hal ini sejalan dengan penelitian Sinaga (2008), penyebab orang memilih bekerja sebagai pemulung antara lain karena tidak ada pilihan lain, mereka pada umumnya berasal dari pendidikan rendah, tidak mempunyai keterampilan serta tidak mempunyai modal dan sulitnya mencari pekerjaan.

Pekerjaan memulung adalah pekerjaan yang memiliki penghasilan tergolong rendah. Sehingga sulit bagi mereka untuk memenuhi kebutuhan-kebutuhan hidupnya. Tak jarang pemulung hanya mampu memenuhi kebutuhan dasarnya saja, bahkan ada pula yang sama sekali tidak mampu memenuhi kebutuhan dasarnya. Rendahnya kemampuan ekonomi pemulung ini mengakibatkan dampak yang buruk seperti gizi buruk, anak yang tidak mendapatkan pendidikan dengan alasan tidak adanya biaya untuk bersekolah, begitupula dengan kesehatan karena mereka tidak memiliki biaya untuk mendapatkan pelayanan kesehatan bila sakit.

Berdasarkan penelitian yang dilakukan oleh Angelyk Y. F. Kawalo dkk (2016), pemulung dalam sehari umumnya makan dua kali pada waktu pagi dan sore hari dengan lauk ikan goreng atau kukus, kadang-kadang ditambah sayuran. Pemulung memenuhi kebutuhan akan sandang dengan membeli pakaian ada yang hanya satu kali dalam setahun, dua kali dalam satu tahun bahkan ada yang tidak pernah membeli pakaian melainkan hanya memperoleh dari pemberian orang ataupun diperoleh dari tempat sampah. Dan mayoritas rumah pemulung terbuat dari kayu/tripleks.

Hasil penelitian ini menunjukkan betapa rendahnya kemampuan ekonomi pemulung dan betapa sulit bagi mereka untuk memenuhi kebutuhan dasarnya. Dengan rendahnya kemampuan ekonomi dan tuntutan kebutuhan dasar yang harus dipenuhi, ini menjadi tantangan tersendiri bagi para komunitas pemulung.

Setiap individu pemulung memiliki tipe yang berbeda-beda. Ada yang mudah bangkit dan mampu bertahan terhadap situasi sulit yang dihadapi, adapula yang tidak mampu bertahan dalam situasi sulit tersebut yang dihadapinya. Seperti halnya dalam memenuhi kebutuhan dasar ditengah kemampuan ekonomi yang rendah dan pekerjaan sebagai pemulung. 


\section{WELVAART}

Begitu halnya yang terjadi pada pemulung yang berada di Kelurahan Petoaha Kota Kendari, dalam melakukan pekerjaannya sebagai pemulung, tak sedikit tantangan hidup yang didapatkan, baik yang bersifat fisik maupun psikis. Seperti hasil penelitian yang telah dilakukan bahwa pemulung di Kelurahan Petoaha memungut sampah dengan menggunakan sampan sebagai sarana utama. Berhubung mereka tinggal di pesisir Teluk Kendari sehingga membuat mereka harus melintasi teluk untuk mengais sampah yang terbawa arus dan yang ada di daratan sebelah.

Tentu hal ini akan lebih beresiko bagi para pemulung di Kelurahan Petoaha dibandingkan dengan pemulung pada umumnya yang hanya melewati jalur darat tanpa harus melintasi teluk. Belum lagi tantangan psikis bagi pemulung seperti orang-orang yang menganggap bahwa pekerjaan memulung memiliki konotasi yang negatif, sehingga memaksa pemulung harus menahan rasa malu demi memenuhi kebutuhan dasarnya.

Keadaan pemulung di Kelurahan Petoaha Kecamatan Nambo Kota Kendari membuat peneliti tertarik untuk mengetahui Resiliensi Pemulung di Kelurahan Petoaha Kecamatan Nambo Kota Kendari. Adapun rumusan masalahnya yaitu bagaimana kondisi kebutuhan dasar pemulung di Kelurahan Petoaha Kecamatan Nambo Kota Kendari dan bagaimana resiliensi pemulung dalam memenuhi kebutuhan dasarnya di Kelurahan Petoaha Kecamatan Nambo Kota Kendari.

\section{METODE}

Metode penelitian yang digunakan dalam penelitian ini adalah kualitatif dan penentuan informan dilakukan dengan teknik purposive sampling, sebagaimana yang dikemukakan oleh Sugiyono (2014) bahwa Purposive Sampling adalah teknik pengambilan sampel sumber data dengan pertimbangan tertentu. Pertimbangan tertentu ini, misalnya orang tersebut yang dianggap yang paling tahu tentang apa yang kita harapkan, atau mungkin dia sebagai penguasa sehingga akan memudahkan peneliti menjelajahi objek/situasi sosial yang diteliti. Informan dalam penelitian ini sebanyak 14 orang yang terdiri dari 8 orang pemulung yang ada di Kelurahan Petoaha, 3 orang aparat Kelurahan Petoaha, 1 orang pembeli barang bekas, dan 2 orang Pegawai Dinas Sosial. Data yang telah dikumpulkan melalui 


\section{WELVAART}

observasi, wawancara, dan studi dokumen kemudian dianalisis secara deskriptif kualitatif.

\section{HASIL DAN PEMBAHASAN}

Menurut Permensos No.8 Tahun 2012, pemulung adalah orang-orang yang melakukan pekerjaan dengan cara memungut dan mengumpulkan barang-barang bekas yang berada di berbagai tempat pemukiman pendudukan, pertokoan dan/atau pasar- pasar yang bermaksud untuk didaur ulang atau dijual kembali, sehingga memiliki nilai ekonomis. Ciri-cirinya, tidak mempunyai pekerjaan tetap dan mengumpulkan barang bekas.

Menurut Twikromo (1997) pemulung adalah orang yang mendapatkan penghasilan dari mengumpulkan barang bekas. Dalam hal ini, terdapat dua kategori pemulung yaitu pemulung jalanan dan pemulung menetap. Pemulung jalanan adalah pemulung yang hidup di jalanan atau dideskripsikan oleh pemerintah sebagai gelandangan atau pemulung liar. Sedangkan pemulung menetap adalah pemulung yang menyewa sebuah rumah secara bersama-sama disuatu yempat tertentu, pemulung yang tinggal di rumah permanen atau semi permanen yang berlokasi di tempat pembuangan akhir atau sekitarnya atau penduduk kampung yang mempunyai mata pencaharian sebagai pemulung (Twikromo, 1997).

1. Jenis Pemulung

Pemulung di Kelurahan Petoaha Kecamatan Nambo Kota Kendari adalah pemulung yang memiliki tempat tinggal dan bukan termasuk pemulung jalanan. Mereka memiliki kehidupan yang lebih teratur. Status kependudukan mereka legal sehingga mereka juga mendapatkan pelayanan sosial berupa bantuan rumah layak huni, raskin dan kartu BPJS.

2. Jam Kerja Pemulung

Banyaknya waktu yang digunakan pemulung untuk mengais sampah adalah berbeda-beda. Ada yang hanya tujuh jam dalam sehari, ada yang delapan jam dalam sehari dan ada pula yang sepuluh jam dalam sehari. Dengan kata lain, pemulung menggunakan waktu untuk mengais sampah sekitar tujuh jam hingga sepuluh jam dalam sehari. 


\section{WELVAART}

3. Pendapatan Pemulung

Pendapatan pemulung tiap kali menimbang sampah hasil pulungan, dimana proses penjualan adalah satu kali dalam dua hari. Banyaknya sampah yang di peroleh berkisar antara $10 \mathrm{~kg}$ sampai $20 \mathrm{~kg}$ dalam sekali menimbang dengan harga perkilonya adalah $\mathrm{Rp} 1.700$, maka pendapatan pemulung berkisar antara Rp 17.000 hingga Rp 34.000 untuk sekali menimbang dalam dua hari mengumpulkan sampah.

4. Kondisi Kebutuhan Dasar Pemulung

Kebutuhan dasar pemulung dapat dilihat dari empat jenis kebutuhan yang tergolong didalamnya, yaitu kebutuhan sandang, kebutuhan pangan, kebutuhan papan, kebutuhan kesehatan dan kebutuhan pendidikan. Sejalan dengan pendapat Sumardi \& Evers (1985) yang menyatakan bahwa kebutuhan dasar atau basic human needs dapat dijelaskan sebagai kebutuhan yang sangat penting guna kelangsungan hidup manusia baik yang terdiri dari kebutuhan atau konsumsi individu (makan, minum, pakaian dan perumahan) maupun keperluan pelayanan sosial tertentu (air minum, sanitasi, transpotasi, kesehatan dan pendidikan).

a. Sandang

Pemulung berusaha untuk memenuhi kebutuhan sandangnya dengan membeli pakaian bekas yang mereka sebut dengan istilah RB. Dengan penghasilan yang tergolong rendah, pemulung memilih pakaian bekas untuk memenuhi kebutuhan sandangnya karena harganya murah. Hal itu dilakukannya agar dapat meminimalisir pengeluaran atau menghemat agar sisa uang yang diperoleh dari hasil memulung dapat digunakan untuk memenuhi kebutuhan yang lainnya. Sedangkan sebagian pakaian yang digunakan pemulung saat memulung diperoleh dari pemberian Anak Buah Kapal (ABK) nelayan yang berlabuh di perairan Teluk Kendari.

b. Pangan

Pemulung berusaha memenuhi kebutuhan pangannya dengan menyesuaikan kemampuan ekonomi yang ia miliki, sehingga pemulung merasa bahwa mesti menghemat pengeluaran atau memanajemen 


\section{WELVAART}

keuangan dengan membeli beras perliter, dan memperbanyak konsumsi ubi dan sagu. Bagi mereka, mengonsumsi sagu dapat menghemat pengeluaran karena harganya murah serta dapat memenuhi kebutuhan pangan dalam beberapa waktu kedepan lebih lama dan hemat dibanding hanya mengonsumsi beras. Akan tetapi tidak luput pula bagi mereka untuk mengonsumsi mie instan sebagai makanan pokok dengan harga terjangkau.

c. Papan

Pemulung memiliki rumah yang dikategorikan oleh Dinas Sosial sebagai rumah tidak layak huni oleh sebab itulah pemulung mendapatkan bantuan rumah layak huni. Artinya pemenuhan kebutuhan papan pemulung dibantu oleh Dinas Sosial dan pemerintah setempat sehingga pemulung hanya berusaha menyisihkan uang untuk membeli papan dan atap yang akan dimanfaatkan dalam pembenahan kerusakan rumah kedepannya.

d. Kesehatan

Pemulung berusaha mendapatkan pelayanan kesehatan dengan cara mengikuti program Jaminan Kesehatan Nasional (JKN) yang dikeluarkan oleh Badan Penyelenggara Jaminan Sosial (BPJS), mengusahakan diri agar terdaftar sebagai peserta. Informan mengakui bahwa tidak banyak yang dapat dilakukannya untuk mendapatkan pelayanan kesehatan kecuali dengan menjadi peserta yang memiliki kartu BPJS Kesehatan, sehingga ia pun dapat mengakses pelayanan kesehatan dengan menggunakan kartu tersebut. Akan tetapi, jika sakit yang dialami informan hanya penyakit yang ringan seperti demam dan influensa, maka cukup bagi informan mengobatinya dengan membeli obat di warung terdekat atau berobat ke dukun.

e. Pendidikan

Pemulung cenderung memiliki pendidikan yang rendah, hanya sebatas tamatan sekolah dasar dan bahkan ada pula yang tidak mengecap bangku sekolah. Pemulung kurang memiliki kemampuan untuk menyekolahkan anaknya sampai jenjang SMA dan lebih berorientasi untuk membiarkan mereka mencari pekerjaan sebagai kuli bangunan untuk 


\section{WELVAART}

membantu memenuhi kebutuhan keluarga sedangkan informan mengambil jalan untuk mengais sampah di perairan Teluk Kendari.

5. Resiliensi Pemulung

a. Social Compentence

Social compentence memiliki beberapa sub aspek yaitu responsiveness, communication, empathy and caring, dan compassion, altruism, forgiveness (Benard, 2004).

Pemulung menunjukkan kemampuannya untuk mendapatkan respon positif dari orang lain dengan cara silaturahim ke rumah tetangga dan melalui saling berbagi makanan, hal ini disebut juga dengan istilah responsiviness. Pemulung memiliki kemampuan untuk mengungkapkan permasalahan yang dihadapinya yaitu masalah ekonomi untuk pemenuhan kebutuhan dasarnya melalui tiga cara. Pertama, memanfaatkan kepercayaan pemilik warung untuk sekiranya dapat memberikan pinjaman beras dan tercatat sebagai utang. Kedua, meminjam beras kepada tetangga. Ketiga, mengambil "panjar" kepada pembeli sampah tempat mereka sering menjual hasil pulungan mereka. Ketiga hal ini merupakan wujud kemampuan communication yang dibangun oleh informan.

Empathy and caring yaitu kemampuan pemulung untuk mengetahui bagaimana perasaan orang lain (Benard, 2004). Dalam hal ini, pemulung menunjukkan empathy and caring-nya melalui saling membantu antara pemulung satu dan yang lainnya tanpa harus menunggu panggilan bantuan terlebih dahulu. Mereka tunjukkan melalui kepeduliannya terhadap teman seprofesinya dalam bentuk saling membantu mengangkat hasil pulungan pada saat proses penimbangan. Sedangkan bentuk altruism pemulung dapat dilihat dari kemurniannya dalam menolong orang yang mengalami kesulitan (Benard, 2004). Hal semacam ini ditunjukkan pemulung melalui berbagi makanan jika berlebih. 


\section{WELVAART}

\section{b. Problem Solving Skill}

Problem Solving Skill memiliki beberapa sub aspek yang meliputi planning, flexibility, resourcefulness, dan critical thingking and insight (Benard, 2004). Planning adalah kemampuan seseorang untuk merencanakan masa depannya. Dalam hal ini, pemulung menunjukkan kemampuan untuk merencanakan masa depannya dan anaknya. Pemulung memiliki keinginan untuk dapat menamatkan sekolah anaknya minimal hingga jenjang Sekolah Menengah Atas (SMA) yang suatu hari nanti akan mendapat pekerjaan yang layak dan kemudian dapat membantu memenuhi kebutuhan keluarga. Flexibility merupakan kemampuan untuk melihat dan usaha untuk mencari jalan keluar, baik untuk masalah kognitif maupun sosial. Termasuk didalamnya kemampuan untuk mencari jalan lain dan tidak terpaku pada satu jalan ketika menghadapi masalah. Dalam hal ini, pemulung berusaha melakukan cara-cara sehingga dapat memaksimalkan potensi yang ada agar memperoleh penghasilan yang cukup untuk memenuhi kebutuhan dasar.

Pemulung menunjukkan kemampuan mencari solusi alternatif terhadap pemenuhan kebutuhan dasarnya dengan cara berangkat memulung diawal hari, memperbanyak frekuensi memulung dalam sehari, memperjauh perjalanan, dan mencari dan menjual kerang sebagai penghasilan tambahan serta mengambil alih penjualan ikan nelayan dan hasilnya mengharapkan pemberian suka rela dari pemilik ikan. Sehingga dapat juga dikatakan bahwa cara-cara yang dilakukan informan seperti yang telah disebutkan di atas merupakaan strategi yang digunakan untuk bertahan hidup ditengah tekanan kebutuhan dasar yang terus menuntut untuk dipenuhi. Inilah bentuk kemampuan informan dalam mencari solusi alternatif terhadap pemenuhan kebutuhan dasarnya, dalam konsep Benard disebut juga dengan istilah Resourcefulness.

Sedangkan kemampuan informan untuk berpikir tingkat tinggi agar dapat memahami situasi kejadian yang sedang dialaminya, ini adalah bentuk critical thingking yang dimiliki informan. Pemecahan masalah yang paling 


\section{WELVAART}

dalam serta persepsi informan mengenai masalah kebutuhan dasarnya dapat diatasinya, ini merupakan bentuk Insight yang tidak tergambar jelas pada informan. Dengan kata lain, informan hanya menunjukkan kemampuan ini dengan kesadarannya akan pentingnya menyekolahkan anak agar keturunannya mendapatkan pekerjaan yang layak sehingga akan memperoleh pendapatan yang cukup ataupun berlebih, dengan begitu anak akan lebih mudah atau tidak mengalami kesulitan dalam memenuhi kebutuhan-kebutuhan dirinya dan keluarganya sebagaimana kesulitan yang dirasakan oleh informan.

c. Autonomy

Autonomy memiliki beberapa aspek yang meliputi positif identity, internal locus of control and initiative, self-efficacy and mastery, adaptive discanding and resistance, self awareness and mindfulness, dan humor (Benard, 2004).

Positive identity adalah identitas tentang diri yang positif dan kuat. Dalam hal ini, pemulung menunjukkannya melalui penilaian baiknya terhadap pekerjaannya sebagai pemulung, sehingga mampu mengabaikan hal-hal negatif yang berasal dari orang lain. berusaha untuk mengabaikan dan tidak mempedulikan perkataan buruk orang lain terhadap mereka. Inilah bentuk resistance yang dimiliki oleh informan. Terpenting bagi informan adalah memanfaatkan potensi dirinya untuk dapat menghasilkan uang sendiri tanpa harus bergantung pada orang lain ataupun mengambil barang orang lain tanpa izin. Inilah bentuk pandangan positif informan terhadap kemampuan dirinya dalam menghadapi masalah, dalam konsep Benard disebut juga dengan istilah positive identity.

Pemulung menunjukkan kemampuan untuk memotivasi diri dalam memenuhi kebutuhan dasarnya dengan memulung tiap harinya dan mencari pekerjaan lain untuk menambah penghasilan berupa cari kerang lalu menjualnya, perhatian dan usaha yang dilakukannya ini adalah untuk memenuhi kebutuhan dasarnya. Hal semacam ini merupakan bentuk perhatian dan usaha informan untuk mencapai apa yang menjadi tujuannya, 


\section{WELVAART}

yaitu pemenuhan kebutuhan dasar, dalam konsep Benard disebut juga dengan internal locus of control and initiative.

Mereka memilih pekerjaan memulung disebabkan karena tidak adanya pekerjaan lain yang dapat diharapkan dan lebih baik serta mampu untuk dikerjakan agar dapat memperoleh penghasilan selain dari memulung. Sehingga, tidak heran mereka memilih untuk mengumpulkan barang bekas (sampah) sebagai satu-satunya pekerjaan yang diharapkan dapat membantu memenuhi kebutuhan dasarnya, terutama kebutuhan akan makanan. Dengan kata lain, informan kurang berkompenten untuk memenuhi kebutuhan dasarnya secara baik, dalam konsep Benard hal seperti ini disebut dengan self efficacy and mastery.

Masalah yang dihadapi pemulung begitu banyak, mulai dari kebutuhan akan makanan, pakaian, rumah sampai pada uang jajan anak yang bersekolah sehingga informan tidak mampu menunjukkan kemampuan untuk mengamati apa yang orang lain pikirkan dan butuhkan. Ini berkaitan dengan kepekaan informan terhadap masalah yang dihadapi orang lain, dalam konsep Benard disebut juga dengan self awareness and mindfulness. Meski seperti itu adanya, namun informan masih sering bercanda dengan keluarga dirumah dan dengan teman-teman pemulung lainnya untuk menciptakan suasana yang gembira sehingga beban hidup terasa lebih ringan (humor).

d. Sense of Purpose

Sense of Purpose memiliki beberapa aspek yang meliputi Goal diretion, Achievement Motivation, and Educational Aspirations, Optimism and hope, Special Interest, Creativity, and Imagination, faith, spirituality, and sense of meaning (Benard, 2004).

Pemulung menyadari bahwa jika dapat menyekolahkan anaknya dengan baik dan setelah itu mendapatkan pekerjaan yang layak, hal itu akan memudahkan masa-masa tua informan sebagai seorang ibu yang lemah dan tak kuat lagi untuk bekerja. Dengan kata lain, bagi informan, pemenuhan kebutuhan dasar keluarga tak lagi menjadi tanggungan seorang diri, akan 


\section{WELVAART}

tetapi juga telah menjadi tanggungan anak. Hal ini merupakan wujud motivasi berprestasi yang dimiliki oleh informan, sehingga menjadikan informan percaya diri dengan pekerjaannya sebagai pemulung dan tetap percaya diri karena bagi informan, pekerjaan memulung bukanlah pekerjaan yang buruk dan tetap halal. Dalam konsep Benard, hal semacam ini disebut juga Goal diretion, Achievement Motivation, and Educational Aspirations.

Harapan pemulung dalam bekerja dan mengabaikan penilaian negatif dari orang lain terhadap pekerjaan mereka adalah agar dapat memenuhi kebutuhan sehari-hari berupa makanan dan agar dapat menyekolahkan anak sehingga dapat memutus rantai kemiskinan yang sedang dialami oleh pemulung. Ini adalah bentuk sikap optimis dan harapan informan. Dalam konsep Benard disebut juga dengan istilah Optimism and hope. Tidak hanya memulung, pekerjaan yang dilakukan oleh informan adalah mencari kerang untuk memenuhi kebutuhan pangan informan sebdiri dan dijual agar mendapatkan penghasilan tambahan. Hal semacam ini merupakan wujud kreativitas pemulung dalam memenuhi kebutuhan dasarnya, dalam konsep Benard disebut juga dengan Special Interest, Creativity, and Imagination.

Sedangkan masalah keagamaan, pemulung terkadang masih meluangkan waktu untuk menyandarkan harapan pada Sang Pencipta. Masih mampu mengandalkan do'a dalam mennjalani kehidupan dengan berbagai rintangan yang dihadapi. Artinya, informan masih mampu mengambil kekuatan dari agama. Inilah bentuk kemampuan informan untuk mengambil kekuatan dari agama dalam menghadapi masalah hidup. Hal ini dalam konsep Benard disebut juga dengan istilah faith, spirituality, and sense of meaning.

\section{KESIMPULAN}

1. Kebutuhan dasar pemulung terdiri atas : a) sandang atau pakaian yang berusaha dipenuhi oleh pemulung dengan membeli pakaian bekas atau disebut dengan istilah "RB", b) pangan atau makanan yang berusaha dipenuhi oleh pemulung dengan membeli beras per liter dan memperbanyak konsumsi ubi dan sagu, c) 


\section{WELVAART}

papan atau perumahan yang berusaha dipenuhi oleh pemulung dengan menyisihkan sedikit demi sedikit hasil pulungan untuk membeli papan dan atap, d) kesehatan yang berusaha dipenuhi oleh pemulung dengan mengandalkan kartu BPJS Kesehatan, membeli obat di warung dan berobat ke dukun, e) pendidikan yang berusaha dipenuhi oleh pemulung dengan menyekolahkan anak paling rendah hingga jenjang Sekolah Menengah Atas (SMA).

2. Resiliensi pemulung dapat dilihat dari empat aspek, yaitu : a) Social compentence yang dimiliki pemulung adalah dengan berbagi makanan kepada tetangga dan saling bantu mengangkat hasil pulungan teman pemulung, b) Problem solving skill yang dimiliki dalam memecahkan masalah kebutuhan dasarnya adalah dengan memperbanyak memulung dan mencari kerang serta menjualkan hasil tangkapan nelayan, c) Autonomy yang dimiliki pemulung terlihat dari kemampuannya untuk mengabaikan pandangan negatif yang datang dari orang lain dan tetap menilai positif pekerjaannya sebagai pemulung, d) Sense of purpose yang dimiliki pemulung terlihat dari kemampuannya menaruh harapan besar pada anaknya agar mampu menyelesaikan sekolahnya paling rendah hingga jenjang Sekolah Menengah Atas.

\section{DAFTAR PUSTAKA}

Benard, Bonnie. (2004). Resiliency : What We Have Learned. San Fransisco : WestEd

Kawalo, Angelyk Y. F., dkk. (2016). Kajian Bertahan Hidup Pemulung di Tempat Pembuangan Akhir Sampah Kelurahan Sumompo Kecamatan Tuminting, Manado. ASE-Volume 12 Nomor 1, Januari 2016 : 47-54

Sinaga. (2008). Kajian Model Pengembangan Usaha di Kalangan Pemulung. Jakarta : Partipation Research.

Sugiyono. (2014). Metode Penelitian Kuantitatif Kualitatif dan R\&D. Bandung : Alfabeta

Sumardi, Muliyanto \& Evers, Hans-Diter. ed. (1985). Kemiskinan dan Kebutuhan Pokok. Jakarta: CV Rajawali. 